\title{
New Method of Quantifying Economic Performance
}

\section{Priyamukh Panalal*}

Department of Economics, GSFC University, Kareli Baug, Vadodara, Gujarat, India

\begin{abstract}
Kupri Index of a country is defined as its GDP in USD per 1,000 person per $1,000 \mathrm{~km}^{2}$ of land. When Kupri Index of 194 countries is calculated, it gave astonishing results. Kupri Index of different categories of countries are analyzed and the conclusion is drawn: The following countries have much better economic performance then the (1)countries which are not in the list of first 10 countries with highest GDP, first 10 countries with highest "Total Individual Wealth", G7 countries, G20 countries and BRICS countries. (2) The Countries with population density more than that of India (409). (3) Countries with area less than 3,000 km2. (4) Countries with low GDP. (5) Kupri Index gives much clear picture of country's economic performance.
\end{abstract}

Keywords: Kupri index; Gross Domestic Product (GDP); Annual percentage GDP growth; Population; Land area

\section{Introduction}

Generally indices like GDP, annual GDP growth rate, GDP per capita, debt, debt/GDP ratio, debt per capita, Human Development Index (HDI) etc., are used for knowing economic performance of a country. All these indices cannot be used for evaluating country's economic performance or comparing economic performance one country with that of another country. Let us see the first two, GDP and annual percentage GDP growth in this context.

\section{GDP}

World Bank has released GDP data of 194 countries for the year 2016. GDP cannot be used for comparing economic performance of countries because bigger countries have more resources and hence have higher GDP [1]. Smaller countries have less resources and hence have lower GDP. China and India occupy 2 nd and 7 th position respectively in GDP ranking. However, as per Kupri Index ranking, China and India are occupying 180th (lowest 15th) and 191st (lowest 4th) position respectively. (Appendix B - Kupri Index ranking table). The reason for this discrepancy between these two methods is that Kupri Index brings all countries at the same level with respect to both productive factors population and land area but GDP does not.

\section{Annual percentage GDP growth}

Generally, annual percentage GDP growth rate is considered as an indicator of economic performance of the country. Indian annual percentage GDP growth for the year 2016 was 7.1 percent, while, as shown in footnote, Indian productivity of per person per $\mathrm{km}^{2}$ of land for the same period was 3.289 paisa (1/33rd of Indian currency rupee). In India, the minimum price of vegetables, fruits and many other items is not less than Rs. 5 and is multiples thereof. This means that Indians have no value of 1 to 5 rupees [2].

The author deeply indebted to Professor Dinkar Naik, Dean, Faculty of Commerce, M.S.University, Vadodara, India for making this article a research paper.

The author thankful to Komal Shah, Nirali Parikh, Pinkesh Kapadia and Rajesh Parikh for their valuable suggestions.

Productivity of India in USD per 1,000 person per $1,000 \mathrm{~km}^{2}$ of land

$=\left(\right.$ GDP in million USDx10 $/\left(\right.$ Populationx $\left.10^{-3}\right)\left(\right.$ Land area $\left.\times 10^{-3}\right)$

$=2,263 \times 10^{6} /\left(326,538,252 \times 10^{-3}\right)\left(9,833,516 \times 10^{-3}\right)$
$=2,263 \times 10^{12} /(326,538,252)(9,833,516)$,

$=512 \times 10^{-6}$ or,

Productivity of India in Indian paisa per person $\mathrm{km}^{2}$ of land

$=512 \times 10^{-6} \times 64.25 \times 100$

$=3,289(1 / 33 \mathrm{rd}$ of a rupee $)$

Note: 1 USD=Rs 64.25 and Indian Currency 1 rupee=100 paisa.

Considering that money lesser than Rs. 5 has no value in India, Indian productivity of $1 / 33 \mathrm{rd}$ of a rupee per person per $\mathrm{km}^{2}$ of land can be considered to be almost "zero". This discrepancy between the Indian annual GDP growth of 7.1 percent and Indian productivity per person per $\mathrm{km}^{2}$ being zero is on account of consideration of productivity in relation to both population land area, which the Kupri Index considers, but the annual GDP growth rate does not.

Similarly criteria like GDP per capita, debt, debt/GDP ratio, debt per capita, Human Development Index(HDI) also do not consider the productive factors, land and population both together and can not be used for comparing economic performance.

\section{Definition of Kupri Index}

When Kupri Index of countries is calculated as USD per person per $\mathrm{km}^{2}$ of land, it results in a fraction and becomes difficult to compare. It is better to define Kupri Index as productivity of the country as USD per 1,000 person per $1,000 \mathrm{~km}^{2}$ of land.

\section{Calculating Kupri Index}

Kupri Index $=$ GDP in USD $/\left(\right.$ Population $\times 10^{-3} \times$ Land area $\left.\mathrm{km}^{2} \times 10^{-3}\right)$ $=\mathrm{GDP}$ in million USD $\times 10^{6} /\left(\right.$ Population $\times$ Land area $\left.\mathrm{km}^{2} \times 10^{-6}\right)$

*Corresponding author: Priyamukh Panalal, Department of Economics, GSFC University, Kareli Baug, Vadodara 390018, Gujarat, India, Tel: +0019 9106625647 E-mail: priyamukh@gmail.com

Received December 07, 2017; Accepted December 31, 2017; Published January 07,2018

Citation: Panalal P (2018) New Method of Quantifying Economic Performance. J Glob Econ 6: 277. doi: 10.4172/2375-4389.1000277

Copyright: ( 2018 Panalal P. This is an open-access article distributed under the terms of the Creative Commons Attribution License, which permits unrestricted use, distribution, and reproduction in any medium, provided the original author and source are credited. 
$=\mathrm{GDP}$ in million USD $\times 10^{12} /\left(\right.$ Population $\times$ Land area $\left.\mathrm{km}^{2}\right)$

Note: GDP (nominal) data of World Bank are in million USD.

For calculating Kupri Index and population density of 194 countries, World Bank GDP data, population data from Worldometer and land area data from Wikipedia are used $[3,4]$.

Appendix-A shows calculations of Kupri Index and population density per $\mathrm{km}^{2}$ of land. Appendix-B is Kupri Index ranking table with respective GDP ranking, is derived from Appendix-A.

\section{Importance of Kupri Index}

India is a better example to discuss as India's annual GDP growth rate of 7.1 percent, $7^{\text {th }}$ position in GDP ranking and $7^{\text {th }}$ position in "Total Individual Wealth" ranking [5] slips down to $191^{\text {st }}$ (lowest $4^{\text {th }}$ ) position with Kupri Index (512). Without Kupri Index, it is impossible to know that a country like India is actually at the 4 th lowest position in economic performance. If India wants to improve its economic performance, India should find the countries having Kupri Index in millions and study the economic conditions prevailing in those countries. Kupri Index is also important in finding the country with higher Kupri Index.

\section{Analysis of Kupri Index Tables}

For analysis six different tables are derived from Appendix-B1-B6. These tables are as under:

1. Analysis of Kupri Index of 10 countries with highest GDP, G76, G207, BRICS8 countries and 10 countries with highest “Total Individual Wealth".

2. Analysis of Kupri Index of 25 countries with highest Kupri Index.

3. Analysis of Kupri Index of 25 countries with lowest Kupri Index.

4. Analysis of Kupri Index of countries with population density higher than that of India.

\begin{tabular}{|c|c|c|c|c|c|c|c|}
\hline S. No. & Country & Member of which Group & $\begin{array}{l}\text { Total Individual Wealth } \\
\text { Billion USD (Ranking) }\end{array}$ & $\begin{array}{l}\text { GDP Million } \\
\text { USD }\end{array}$ & GDP Ranking & Kupri Index & Kupri Index Ranking \\
\hline 1 & S. Korea & G20 & - & 312,798 & 11 & 277,711 & 55 \\
\hline 2 & UK & F10,G7,G20,TIW & $9,200(5)$ & $2,618,885$ & 5 & 164,826 & 70 \\
\hline 3 & Germany & F10,G7,G20,TIW & $(, 400(4)$ & $3,466,756$ & 4 & 120,372 & 78 \\
\hline 4 & Japan & F10,G7,G20,TIW & $15,200(3)$ & $4,939,383$ & 3 & 103,634 & 80 \\
\hline 5 & Italy & F10,G7,G20,TIW & $4,500(8)$ & $1,849,970$ & 8 & 102,665 & 81 \\
\hline 6 & France & F10,G7,G20,TIW & $7,600(6)$ & $2,485,453$ & 6 & 58,964 & 94 \\
\hline 7 & Turkey & G20 & - & 857,748 & 18 & 13,612 & 120 \\
\hline 8 & S. Arabia & G20 & - & 646,438 & 20 & 9,759 & 130 \\
\hline 9 & Australia & G20, TIW & $4,500(9)$ & $1,232,068$ & 12 & 6,852 & 136 \\
\hline 10 & USA & F10,G7,G20,TIW & $48,700(1)$ & $18,569,100$ & 1 & 5,782 & 140 \\
\hline 11 & S. Africa & $\mathrm{G} 20, \mathrm{~B}$ & - & 312,798 & 33 & 4,620 & 148 \\
\hline 12 & Argentina & G20 & - & 545,860 & 21 & 4,433 & 150 \\
\hline 13 & Canada & F10,G7,G20,TIW & $4,700(10)$ & $1,529,760$ & 10 & 4,182 & 151 \\
\hline 14 & Mexico & G20 & - & $1,045,998$ & 16 & 4,070 & 154 \\
\hline 15 & Indonesia & G20 & - & 932,259 & 16 & 1,856 & 172 \\
\hline 16 & Brazil & $\mathrm{F} 10, \mathrm{G} 20, \mathrm{~B}$ & - & $1,796,186$ & 9 & 998 & 180 \\
\hline 17 & China & F10,G20,TIW & $17,300(2)$ & $11,199,145$ & 2 & 850 & 181 \\
\hline 18 & Russia & G20,B & - & $1,283,162$ & 13 & 524 & 190 \\
\hline 19 & India & $\mathrm{F} 10, \mathrm{G} 20, \mathrm{~B}, \mathrm{TIW}$ & $5,200(7)$ & $2,263,522$ & 7 & 512 & 192 \\
\hline
\end{tabular}

Table 1: Analysis of Kupri index of 19 countries belonging to first 10 highest GDP ranking, G7, G20, 10 highest total individual wealth and BRICS countries.
5. Analysis of Kupri Index of countries with land area less than $3,000 \mathrm{~km}^{2}$.

6. Analysis of Kupri Index of countries with lowest GDP.

Analysis of Kupri index of 19 countries belonging to first 10 highest GDP ranking, G7, G20, 10 highest total individual wealth and BRICS countries

In the lists of first 10 GDP ranking countries, G7 countries, G20 countries, BRICS countries and 10 highest total Individual Wealth countries, many countries repeat and hence instead of five separate tables, all countries are included in one table only. Third column of this table shows that which country belongs to which group. F10 represents member of first 10 countries with highest GDP ranking, G7 represents G7 countries, G20 represents G20 countries, B represents BRICS countries and TIW represents 10 highest Total Individual Wealth countries. EU is a member of G20 countries. As European Union (EU) is a group of European countries and many EU countries are members of G20 countries, EU as such is excluded from this list. So there are only 19 countries in this list.

From the Table 1 it is observed that:

i. Out of 194 countries, fastest growing two economies, namely India and China with their annual economical growth of 7.1 percent and 6.7percent respectively and with GDP ranking $7^{\text {th }}$ and $2^{\text {nd }}$ respectively and $7^{\text {th }}$ and $2^{\text {nd }}$ position in total Individual Wealth ranking slip down to $191^{\text {st }}$ (i.e., $4^{\text {th }}$ lowest) and 180th (i.e., $15^{\text {th }}$ lowest) position respectively.

ii. Out of 19 countries, 13 (68.4 percent) countries slip down to 100 lowest position in Kupri Index ranking.

iii. 10 countries with highest GDP namely USA, China, Japan, Germany, UK, France, India, Italy, Brazil and Canada slip down to position $139^{\text {th }}, 180^{\text {th }}, 80^{\text {th }}, 78^{\text {th }}, 70^{\text {th }}, 94^{\text {th }}, 191^{\text {st }}, 81^{\text {st }}, 179^{\text {th }}$ and $151^{\text {st }}$ respectively in the list of Kupri Index ranking.

iv. G7 countries are major advanced economies and have 64 percent of net global wealth. In Kupri Index ranking, G7 countries namely USA, UK, France, Canada [4-6] 
v. Italy, Japan and Germany slip down to $139^{\text {th }}, 70^{\text {th }}, 94^{\text {th }}, 151^{\text {st }}$, $81^{\text {st }}, 80^{\text {th }}$ and $78^{\text {th }}$ position respectively in Kupri Index ranking.

vi. G20 countries are major economies and have 85percent of world trade products. In G20 countries, maximum Kupri Index 277,711 is of South Korea with Kupri Index raking position $57^{\text {th }}$. This means that not a single country from the list of G20 countries is there in the list of first 56 countries with highest Kupri Index. This list also includes 10 countries with highest GDP, G7, BRICS and 10 countries with highest "Total Individual Wealth" countries [7].

vii. In Kupri Index ranking, BRICS countries namely Brazil, Russia, India, China and South Africa also called newly advanced economically developing countries slip down to $179^{\text {th }}, 189^{\text {th }}$, $191^{\text {st }}, 180^{\text {th }}, 148^{\text {th }}$ position respectively in Kupri Index ranking.

viii. 10 countries with highest total Individual Wealth namely USA, China, Japan, Germany, UK, France, India, Canada, Australia and Italy slip down to $139^{\text {th }}, 180^{\text {th }}, 80^{\text {th }}, 78^{\text {th }}, 70^{\text {th }}, 94^{\text {th }}, 191^{\text {st }}, 151^{\text {st }}$, $135^{\text {th }}$ and $81^{\text {st }}$ position respectively in Kupri Index ranking.

ix. Except South Africa, remaining 18(94.7 percent) countries are from first 21 countries with highest GDP.

\section{Analysis of Kupri index analysis of 25 countries with highest Kupri index}

From Table 2, it is observed that:

i. Out of 25 countries, 16 (64 percent) countries have their GDP ranking from 150 to 194 (lowest GDP raking 44 countries).

ii. 20 (80 percent) countries have their GDP ranking from 100 to 194.

ii. Eight (32 percent nearly $1 / 3^{\text {rd }}$ ) countries have their GDP ranking from 177 to 194 (lowest GDP ranking 18 countries).

iii. Six countries have Kupri Index between 4 million to 10 million.

iv. 15 countries have Kupri Index between 12 million to 100 million.

v. Four countries have Kupri Index more than 100 million.

vi. Out of 25 countries, 21 (84 percent) countries have their land area less than $10,000 \mathrm{~km}^{2}$, two (eight percent) countries have land area between 3,000 to $10,000 \mathrm{~km}^{2}$ and two (eight percent) countries have land area between more than $10,000 \mathrm{~km}^{2}$ two (eight percent) countries have land area between more than $10,000 \mathrm{~km}^{2}[8]$

vii. In tables of Kupri Index of 10 countries highest GDP, G7, G20, BRICS and total Individual Wealth countries, highest Kupri Index is 277,411 of South Korea and in Table 1, 25 countries with maximum Kupri Index, lowest Kupri Index is 4,831,342 of Federated States of Micronesia. Minimum Kupri Index $4,831,342$ of Federated States of Micronesia is 17.41 times more than that of South Korea's maximum Kupri Index 271,524 of Table 1.

viii. In the world there are only five countries namely Macau, British Virgin Islands, Brunei, Palau and Liechtenstein with 0percent [7] external debt. British Virgin Islands is not included by World Bank in GDP ranking. Remaining all four countries are from the list of first 28 countries with highest Kupri Index.

ix. First country from the list of first 10 countries with highest GDP , G7, G20, BRICS and first 10 countries with highest "Total Individual Wealth" to enter the list of highest Kupri Index list is Switzerland with Kupri Index ranking 55. That means that in the list of 54 countries with highest KuPri Index, not a single

\begin{tabular}{|c|c|c|c|c|c|}
\hline S. No. & Country & GDP Million USD & GDP Ranking & Kupri Index & Kupri Index Ranking \\
\hline 1 & Liechtenstein & 5,488 & 151 & $902,109,305$ & 1 \\
\hline 2 & Macau & 46,178 & 84 & $660,198,858$ & 2 \\
\hline 3 & Tuvalu & 38 & 194 & $146,505,459$ & 3 \\
\hline 4 & Andorra & 3,249 & 161 & $101,227,643$ & 4 \\
\hline 5 & Malta & 9,643 & 138 & $72,562,339$ & 5 \\
\hline 6 & Singapore & 292,739 & 38 & $63,951,958$ & 6 \\
\hline 7 & Saint Kitts and Nevis & 852 & 182 & $57,474,299$ & 7 \\
\hline 8 & Faroe Islands & 2,613 & 165 & $38,642,033$ & 8 \\
\hline 9 & Barbados & 4,355 & 159 & $34,714,794$ & 9 \\
\hline 10 & Seychelles & 1,423 & 174 & $31,779,831$ & 10 \\
\hline 11 & Bahrain & 32,221 & 96 & $29,671,578$ & 11 \\
\hline 12 & Antigua and Barbuda & 1,221 & 177 & $29,629,536$ & 12 \\
\hline 13 & Maldives & 3,062 & 164 & $27,324,885$ & 13 \\
\hline 14 & Grenada & 884 & 181 & $23,550,084$ & 14 \\
\hline 15 & Greenland & 2,441 & 166 & $20,038,005$ & 15 \\
\hline 16 & Marshall Islands & 187 & 192 & $19,444,219$ & 16 \\
\hline 17 & Saint Vincent \& the Grenadines & 729 & 185 & $17,051,882$ & 17 \\
\hline 18 & Hong Kong & 309,929 & 34 & $15,195,170$ & 18 \\
\hline 19 & Saint Lucia & 1,404 & 176 & $12,116,304$ & 19 \\
\hline 20 & Luxembourg & 57,794 & 75 & $7,858,563$ & 20 \\
\hline 21 & Brunei & 17,105 & 113 & $6,826,970$ & 21 \\
\hline 22 & Qatar & 166,908 & 55 & $6,160,719$ & 22 \\
\hline 23 & Tonga & 434 & 188 & $5,381,220$ & 23 \\
\hline 24 & Mauritius & 12,630 & 129 & $4,831,342$ & 24 \\
\hline 25 & Federated States of Micronesia & 318 & 189 & $4,269,315$ & 25 \\
\hline
\end{tabular}

Table 2: Analysis of Kupri index analysis of 25 countries with highest Kupri index. 
countries from the list of first 10 countries with highest GDP, G7, G20, BRICS and first 10 countries with highest

x. "Total Individual wealth" countries is there.

\section{Analysis of 25 countries with lowest Kupri Index}

From the Table 3, it is observed that:

i. In the list of 25 countries of lowest Kupri Index, four countries namely Brazil, Russia, India and China are of five BRICS countries known as developing countries are there.

ii. Out of 25 countries, five( 20 percent $)$ countries are the countries with their GDP ranking from 2 to 16.

iii. In the list of 25 countries with lowest Kupri Index, 11 countries have their GDP ranking 1 to 100 [9].

Analysis of Kupri index analysis of the countries having population density per $\mathbf{~ k m}^{2}$ more than that of India (409)

For India's low Kupri Index, generally many people are of the opinion that India's big number of population in denominator in Kupri Index equation. There are two reasons to argue that this may not be true.

In Appendix-B of Kupri Index ranking, out of 194 countries, there are only 16 countries having population density more than that of India i.e., 409 per $\mathrm{km}^{2}$. Surprisingly all 16 countries have very high Kupri Index compared to India. Some countries have Kupri Index in thousands and millions against India's Kupri Index in hundreds (512).

From the Table 4, it is observed that:

i. Out of 17 countries, even though India has lowest population density (409 per $\mathrm{km}^{2}$ ), India has lowest Kupri Index 512. It should be noted that India has higher annual growth rate (7.1 percent) and occupies 7 th position in GDP ranking.

ii. Out of 194 countries of the world, Macau has highest Kupri Index-660,198,858 with highest population density 5,261 per $\mathrm{km}^{2}$ ). In this list nearest country to India with respect to Kupri Index, is Bangladesh with Kupri Index 8,015 which is 15.65 times more than that of India.

iii. Eight (47.0 percent) countries with highest population density (more than 1,000) per $\mathrm{KM}^{2}$ have KuPri Index ranking in the world.

iv. 12 (70.9 percent) countries have their Kupri Index in millions.

v. One country namely Macau has Kupri Index 2/3rd of trillion.

vi. Only four countries have Kupri Index in thousands but much higher than that of India (512).

In Table 4 India is the only country having Kupri Index in hundreds. This proves that countries with higher population density are performing much better than the countries with low population density with the exception of India [10].

\section{Analysis of Kupri index of countries with land area less than $3,000 \mathrm{~km}^{2}$}

From the Table 5, it is observed that:

i. Out of 194 countries, there are only 29 countries having their land area less than $3,000 \mathrm{~km}^{2}$.

ii. Out of 29 countries, 27(93.1 percent) countries are from 38 countries with highest Kupri Index (Appendix B).

iii. One country has Kupri Index between 50,000 to 100,000.

\begin{tabular}{|c|c|c|c|c|c|}
\hline S. No. & Country & GDP Million USD & GDP Ranking & Kupri Index & Kupri Index Ranking \\
\hline 1 & Malawi & 4,258 & 160 & 1,962 & 170 \\
\hline 2 & Indonesia & 932,259 & 16 & 1,856 & 171 \\
\hline 3 & Myanmar & 64,866 & 71 & 1,747 & 172 \\
\hline 4 & Algeria & 166,839 & 56 & 1,705 & 173 \\
\hline 5 & Zambia & 21,202 & 106 & 1,632 & 174 \\
\hline 6 & South Sudan & 13,282 & 126 & 1,636 & 175 \\
\hline 7 & Pakistan & 269,971 & 41 & 1,555 & 176 \\
\hline 8 & Mauritania & 5,061 & 153 & 1,150 & 177 \\
\hline 9 & Sudan & 84,067 & 65 & 1,056 & 178 \\
\hline 10 & Brazil & $1,796,186$ & 9 & 998 & 179 \\
\hline 11 & China & $11,199,145$ & 2 & 860 & 180 \\
\hline 12 & Afghanistan & 19,199 & 110 & 860 & 181 \\
\hline 13 & Tanzania & 44,895 & 85 & 832 & 182 \\
\hline 14 & Somalia & 5,707 & 149 & 785 & 183 \\
\hline 15 & Chad & 13,922 & 124 & 723 & 184 \\
\hline 16 & Madagascar & 10,593 & 137 & 703 & 185 \\
\hline 17 & Mozambique & 15,938 & 118 & 672 & 186 \\
\hline 18 & Central African Republic & 1,723 & 171 & 542 & 187 \\
\hline 19 & Ethiopia & 61,537 & 74 & 533 & 188 \\
\hline 20 & Russia & $1,283,162$ & 12 & 524 & 189 \\
\hline 21 & Mali & 12,037 & 131 & 519 & 190 \\
\hline 22 & India & $2,263,522$ & 7 & 512 & 191 \\
\hline 23 & $\begin{array}{l}\text { Democratic Republic of } \\
\text { Congo }\end{array}$ & 35,238 & 94 & 182 & 192 \\
\hline 24 & Republic of Congo & 14,177 & 123 & 71 & 193 \\
\hline 25 & Niger & 8,169 & 143 & 33 & 194 \\
\hline
\end{tabular}

Table 3: Analysis of 25 countries with lowest Kupri index. 
Page 5 of 8

\begin{tabular}{|c|c|c|c|c|c|c|}
\hline S. No. & Country & Population Density per $\mathbf{k m}^{2}$ & GDP Million USD & GDP Ranking & Kupri Index & Kupri Index Ranking \\
\hline 1 & Macau & 5,261 & $4,61,778$ & 84 & $660,198,858$ & 2 \\
\hline 2 & Singapore & 7,316 & $2,92,739$ & 38 & $63,951,958$ & 6 \\
\hline 3 & Malta & 1,330 & 9,643 & 138 & $72,562,339$ & 5 \\
\hline 4 & Barbados & 650 & 4,355 & 159 & $34,714,794$ & 10 \\
\hline 5 & Bahrain & 1,855 & 32,221 & 96 & $29,671,578$ & 12 \\
\hline 6 & Maldives & 1,261 & 3,062 & 164 & $19,444,219$ & 14 \\
\hline 7 & Marshall Islands & 415 & 187 & 192 & $19,444,219$ & 17 \\
\hline 8 & Hong Kong & 2,687 & $3,09,929$ & 34 & $15,195,170$ & 19 \\
\hline 9 & Mauritius & 628 & 12,630 & 129 & $48,31,342$ & 24 \\
\hline 10 & Israel & 429 & $2,95,075$ & 36 & $17,11,925$ & 34 \\
\hline 11 & Bermuda & 1,323 & 5,574 & 150 & $14,08,570$ & 38 \\
\hline 12 & Netherlands & 410 & $7,70,845$ & 18 & $10,89,293$ & 41 \\
\hline 13 & South Korea & 506 & $14,11,245$ & 11 & $2,77,711$ & 55 \\
\hline 14 & Lebanon & 577 & 47,103 & 83 & 76,041 & 84 \\
\hline 15 & Rwanda & 462 & 7,890 & 145 & 24,620 & 111 \\
\hline 16 & Bangladesh & 1,116 & $1,95,079$ & 47 & 8,015 & 132 \\
\hline 17 & India & 409 & $22,63,522$ & 7 & 512 & 192 \\
\hline
\end{tabular}

Table 4: Analysis of Kupri index analysis of the countries having population density per $\mathrm{km}^{2}$.

\begin{tabular}{|c|c|c|c|c|c|}
\hline S. No. & Country & GDP Million USD & GDP Ranking & Kupri Index & Kupri Index Ranking \\
\hline 1 & Liechtenstein & 5,488 & 151 & $902,109,305$ & 1 \\
\hline 2 & Macau & 46,178 & 84 & $660,198,858$ & 2 \\
\hline 3 & Tuvalu & 38 & 194 & $146,505,459$ & 3 \\
\hline 4 & Andorra & 3,249 & 161 & $101,227,643$ & 4 \\
\hline 5 & Malta & 9,643 & 138 & $72,562,389$ & 5 \\
\hline 6 & Singapore & 292,739 & 38 & $63,951,958$ & 6 \\
\hline 7 & Saint Kitts \& Nevis & 852 & 182 & $57,474,299$ & 7 \\
\hline 8 & Faroe Islands & 2,613 & 165 & $38,642,033$ & 8 \\
\hline 9 & Luxembourg & 57,794 & 75 & $38,247,537$ & 9 \\
\hline 10 & Barbados & 4,355 & 159 & $34,714,794$ & 10 \\
\hline 11 & Seychelles & 1,423 & 174 & $31,779,831$ & 11 \\
\hline 12 & Bahrain & 32,221 & 96 & $29,671,578$ & 12 \\
\hline 13 & Antigua \& Barbados & 1,221 & 177 & $29,629,536$ & 13 \\
\hline 14 & Maldives & 3,062 & 164 & $27,324,885$ & 142 \\
\hline 15 & Grenada & 884 & 181 & $23,550,084$ & 15 \\
\hline 16 & Marshall Islands & 187 & 192 & $19,444,219$ & 17 \\
\hline 17 & Saint Vincent \& Grenadine & 729 & 185 & $17,051,882$ & 18 \\
\hline 18 & Hong Kong & 309,929 & 34 & $15,195,170$ & 19 \\
\hline 19 & Saint Lucia & 1,404 & 176 & $12,116,304$ & 20 \\
\hline 20 & Tonga & 434 & 188 & $5,381,220$ & 23 \\
\hline 21 & Mauritius & 12,630 & 129 & $4,831,342$ & 24 \\
\hline 22 & Federated States of Micronesia & 337 & 190 & $4,269,315$ & 25 \\
\hline 23 & Palau & 251 & 191 & $2,483,254$ & 28 \\
\hline 24 & Kiribati & 167 & 193 & $1,768,133$ & 31 \\
\hline 25 & Sao Tome \& Principe & 337 & 189 & $1,760,282$ & 32 \\
\hline 26 & Samoa & 800 & 184 & $1,437,819$ & 37 \\
\hline 27 & Bermuda & 5,574 & 150 & $1,408,570$ & 38 \\
\hline 28 & Comoros & 624 & 186 & 371,207 & 53 \\
\hline 29 & Dominica & 524 & 187 & 64,914 & 87 \\
\hline
\end{tabular}

Table 5: Analysis of Kupri index of countries with land area less than $3,000 \mathrm{~km}^{2}$.

iv. One country has Kupri Index between 100,000 to 1,000,000.

v. Eight countries have Kupri Index between 1,000,000 to $10,000,000$.

vi. 15 countries have Kupri Index between $10,100,000$ to $100,000,000$.

vii. Four countries have Kupri Index between 100,000,000 to
$999,000,000$.

viii. Out of 29 countries, lowest Kupri Index 64,914 is of Dominica. This Kupri Index is 126.78 times more than that of India and 4.27 times more than the highest Kupri Index 277,711 of South Korea from the Table 2 of 10 highest GDP, G7, G20, BRICS and total Individual wealth countries.

ix. Out of 29 countries, 22 (75.8 percent) countries are from the 
list of 45 lowest GDP (GDP from 150 to 194). This proves that countries with smaller area have much better economic performance than that of countries with bigger area [11].

\section{Analysis of Kupri index of countries with lowest GDP ranking}

From Table 6, it is observed that:

i. Out of 15 countries, 10 (66.66 percent) countries have their Kupri Index in millions. In this list of lowest GDP, Kupri Index of Guinea Bissau is 17,303 which 33.79 times more than that of India.

ii. Tuvalu which is at $194^{\text {th }}$ position in GDP ranking occupies $3^{\text {rd }}$ position in Kupri Index while India which is at $7^{\text {th }}$ position in GDP ranking occupies $191^{\text {st }}$ position in Kupri Index ranking.

This proves that countries with lowest GDP are performing economically much better than countries with higher GDP [12].

\section{Application of Kupri Index}

For improving lower Kupri Index of a particular country, the economic conditions of that country should be compared with the country having higher Kupri Index. How to select country with higher Kupri Index? There are tax haven countries with very high Kupri Index in millions. Generally, illegal money is transferred to most of tax haven countries. Such countries should be avoided for comparison. Countries with low Kupri Index have many negative factors that reduce Kupri Index. Countries with high Kupri Index have many positive factors points that increase Kupri Index. For improving Kupri Index, country with lower Kupri Index will have to set up "Kupri Index Research Team - KIRT". KIRT team members will find out positive factors of other countries with higher KuPri Index. Positive factors can be cashless economy, less or practically no defense expenses, higher rating in ease of doing business etc. [13]. It is also of utmost important for KIRT team to find negative factors of the country that decrease Kupri Index. These negative factors can be black money generated by corruption, business and tax evasion, lack of infrastructure, low ranking in "Ease of doing business etc. KIRT team should also visit countries with higher Kupri Index to study positive factors of other countries with high Kupri Index.

\begin{tabular}{|c|c|c|c|c|}
\hline $\begin{array}{c}\text { S. } \\
\text { No. }\end{array}$ & Country & GDP Ranking & Kupri Index & $\begin{array}{c}\text { Kupri Index } \\
\text { Ranking }\end{array}$ \\
\hline 1 & The Gambia & 180 & 37,513 & 105 \\
\hline 2 & Grenada & 181 & $23,550,084$ & 15 \\
\hline 3 & Saint Kitts and Nevis & 182 & $57,474,299$ & 7 \\
\hline 4 & Vanuatu & 183 & 241,824 & 57 \\
\hline 5 & Samoa & 184 & $1,437,819$ & 37 \\
\hline 6 & Saint Vincent and the & 185 & $17,051,882$ & 18 \\
\hline 7 & Grenadines & 186 & 371,207 & 53 \\
\hline 8 & Comoros & 187 & 64,914 & 87 \\
\hline 9 & Dominica & 188 & $5,381,220$ & 23 \\
\hline 10 & Tonga & 189 & $1,760,282$ & 32 \\
\hline 11 & São Tomé and Príncipe & 190 & $4,269,315$ & 25 \\
\hline 12 & Micronesia & 191 & $2,483,254$ & 28 \\
\hline 13 & Marshall Islands & 192 & $19,444,219$ & 17 \\
\hline 14 & Kiribati & 193 & $1,768,133$ & 31 \\
\hline 15 & Tuvalu & 194 & $146,505,459$ & 3 \\
\hline \multicolumn{2}{|r|}{ Table 6: Analysis of Kupri index of countries with lowest GDP ranking. } \\
\hline
\end{tabular}

\section{Reliability of Kupri Index}

As shown above Indian productivity per person per $\mathrm{km}^{2}$ of land indicates that the position of India in Kupri Index ranking table should be among the countries with lowest Kupri Index ranking and in reality it is lowest $4^{\text {th }}$ position. This proves the reliability of Kupri Index.

When Kupri Index is calculated, it shows unbelievable results. Let us take an example of 4 countries India, Somalia, Sudan and Myanmar from the list of 25 countries with lowest Kupri Index (Table 3). When GDP ranking of India is seven and its annual GDP growth rate is 7.1 percent, looking at Kupri Index figures, it is difficult to believe that India occupies lower position than that of Somalia, Sudan and Myanmar in Kupri Index ranking. One is tempted to say that Kupri Index figures cannot be relied upon because how the Kupri Index of Somalia, Sudan and Myanmar can be more than that of India? The reason for India's lower position in Kupri Index ranking is due to many Special negative factors that reduce Kupri Index.

Negative factors can be divided into two categories:

- General negative factors that are common to many countries e.g. lack of Infra Structure, Corruption, Black Money, low ranking in "Ease of doing business" etc.

- Special negative factors which are there only in a particular country.

India has many general negative factors and major special negative factors. Many major negative factors that reduce India's Kupri Index are not there in Somalia, Sudan and Myanmar. Few examples are as follows:

i. Large amount of money, gold and precious stones are with Indian temples. As per one estimate [10] only one Padmanabha Swami Temple in Kerala has worth more than 1,000 million USD. This amounts to $50 \%$ of India's GDP (2,073 million USD) for the year 2015. It is interesting to note as per Oxfam report of 2017, total worth of 10 richest persons of the world for the year 2017 is 590.4 billion USD [11] which is even less than $2 / 3^{\text {rd }}$ of Padmanabha Swami Temple's worth. Eight richest person's total worth is equal to the total worth of the poorest $50 \%$ of world's population (36 billion people). Total worth of eight richest people of the world is nearly 513.5 billion USD [11]. This means that the total worth of Padmanabha Swami temple is almost double to the total worth of poorest 36 billion people of the world. This money and precious stones are donated by Indian people.

ii. Large amount of money is siphoned out of the country to tax haven countries e.g., Panama papers.

iii. This year during Durga Puja celebration, $22 \mathrm{~kg}$ gold saree for Ma Durga (Goddess) costing Rs. 650 million (1 million USD) is used [12].

iv. 450 Tons of dehydrated butter (Ghee) costing Rs 210 million (3.2 million USD) is wasted by pouring (Abhishek) on Goddess village near Gandhinagar, capital of Gujarat State [13].

v. There are so many self proclaimed god in India. They all have their disciples who donate them large amount of money. This also adds to non productive assets.

vi. Large amount of gold is donated to temple to make the temple golden. 
vii. In India politics and religion are not separated and government spent public money for religious purpose.

viii. Indian Government gives subsidy to Muslim community for pilgrimage (Haj Yatra) purpose. Not a single Muslim country gives subsidy to their people for pilgrimage purpose. Of course this is to be phased out by the year 2022 .

ix. India is the only country where Members of Parliament (MP) decides their pay. MPs start getting pension just by signing attendance register only once even without attending Parliament. Many MPs have criminal report. Most of MPs becomes rich within one or two year. There are many such examples like this. The above mentioned major negative factors are not there in Sudan, Somalia and Myanmar.

\section{Limitations of Kupri Index}

For calculating Kupri Index, total population and total land area have been considered. Actually instead of total population and total land area, number of productive people and productive land area should be considered. It is difficult to get exact number of productive people and productive land area. In both cases approximate figures can be calculated as follows.

\section{Number of productive people}

This depends upon average age at which person start working, average age at which person retires and average life expectancy. Let us take an example of India. In India parents support for education of their children. Average age of graduation is 21 years. Many students get more than double degree. Some students start working earlier to support their family. Under these circumstances, let us consider an average age at which person start working is 17 years. Official retirement age in India is between 58 to 65 years or average retirement age 61 years. Some people continue to work after retirement. Life expectancy in India is average 68 years. Under these circumstances, overall retirement age can be considered 65 years.

Number of productive people $=$ Total population-number of people under the age of 17 years-Number of people above age of 65 .

\section{Total productive land}

Economic performance is the reflection of Government's economic policy. Government should not be blamed for country's geographical location. For comparison purpose all countries should be brought to the same level with respect to land. Land is of three types:

\section{Productive}

2. Semi productive and

\section{Nonproductive}

Productive land: Productive land is used for agricultural purpose, mining industries and fishing industries etc. for all 12 months of the year. There is no need of correction.

Semi productive land: Semi productive land is used only one season (summer) for agricultural purpose due weather conditions. E.g., European and North American countries. Due to winter season, agricultural production is halved. To bring all countries to the same level with respect to land productivity, value of agricultural products and fishing industries should be doubled for calculating GDP. Dairy products are included in agricultural products. But dairy products are produced in all seasons. So only value of crop production and fishing industries should be doubled.

Corrected GDP=Uncorrected GDP+Value of crop and fishing Industries.

Corrected GDP value should be used for Kupri Index calculation.

Nonproductive land: Nonproductive land is the land area there is no agricultural production, no mining industries, no fishing industries, no oil production. If any country has non productive land, area of nonproductive land should be deducted from the total land area.

Corrected land area=Land area-non-productive land area.

Corrected Kupri Index=Corrected GDP/(corrected number of productive people $\times$ Corrected productive land area)

Corrections required to be done vary from country to country. Due to many variables, it is difficult to get exact Kupri Index. Corrected Kupri Index may not be exact but nearer to exact.

\section{Conclusion}

(1) Kupri Index is much better criterion for evaluating country's economic performance or for comparing economic performance of two or more countries than any other criteria.

(2) Kupri Index shows where the country stands in economic performance.

(3) Kupri Index opens up the window for further economic improvements.

(4) Indian productivity is almost nil per person per $\mathrm{km}^{2}$ of land.

(5) Kupri Index is useful in finding the country with which comparison is to be made for further improvements.

(6) In the list of countries with population density (409) higher than that of India economic performance of countries with population density more than that of India is much better.

(7) Economical performance of countries with smaller area is much better than that of countries with bigger area.

(8) Economical performance of countries with low GDP is much better than that of countries with higher GDP.

\section{References}

1. Rajewski Z (1994) Gross domestic product. Eastern European Economics 32 71-80.

2. Mielnik O, Goldemberg J (2002) Foreign direct investment and decoupling between energy and gross domestic product in developing countries. Energy Policy 30:87-89.

3. Yamarone R (2012) Gross Domestic Product. The Trader's Guide to Key Economic Indicators, pp: 11-46.

4. Egerer M, Erich L, Markus Z (2016) Regional Assessment of Global Change Impacts. Springer International Publishing, pp: 147-152.

5. Davenport K (1995) Gross domestic product. WEST AFRICA

6. Murry DA, Gehuang DN (1994) A definition of the gross domestic ProductElectrification interrelationship. The Journal of Energy and Development 19 : 275-283.

7. Neill DO (2014) Gross domestic product. Degrowth: A Vocabulary for a New Era, pp: 1-252.

8. Sutton PC, Elvidge CD, Ghosh T (2007) Estimation of Gross Domestic Product at Sub-National Scales using Night Time Satellite Imagery. International Journal of Ecological Economics \& Statistics 8: 5-21. 
9. Hartl DL, Clark AG (1998) Principles of Population Genetics. Sunderland: Sinauer associates.

10. Excoffier L, Laval G, Schneider S (2005) Arlequin (Version3): An Integrated Software Package for Population Genetics Data Analysis. Evolutionary Bioinformatics Online, pp: 1: 47-50.

11. Ehrlich P (1970) The Population Bomb. New York Times, pp: 1-47.
12. Radloff LS (1977) The CES-D scale: A self-Report Ddepression Scale for Research in the General Population. Applied Psychological Measurement 3 : $385-401$.

13. Weir BS, Clark CC (1984) Estimating F-Statistics for the Analysis of Population Structure. Evolution 38: 1358-1370. 